\title{
Bracken (Pteridium aquilinum)-Induced DNA Adducts in Mouse Tissues Are Different from the Adduct Induced by the Activated Form of the Bracken Carcinogen Ptaquiloside
}

\author{
R. N. Freitas,*`† P. J . O’Connor,* A. S. Prakash, $¥$ M. Shahin, $\neq$ and A. C. Povey*, $\S^{\prime 1}$ \\ *Cancer Research Campaign Carcinogenesis Group, Paterson Institute for Cancer Research, Manchester, M20 9BX United \\ Kingdom; †School of Nutrition, Federal University of Ouro Preto, Ouro Preto, Minas Gerais, 35400-000, Brazil; ¥National \\ Research Centre for Environmental Toxi cology, 39 Kessels Road, Coopers Plains, Queensland 4108, Australia; and \\ $\S S c h o o l$ of Epidemiology and Health Sciences, University of Manchester, Manchester M13 9PT, United Kingdom
}

Received J anuary 22, 2001

Following treatment with bracken fern (Pteridium aquilinum) extract and bracken spores a number of DNA adducts were detected by ${ }^{32} \mathrm{P}$-postlabeling. Three of these adducts have been described previously (Povey et al., Br. J . Cancer (1996) 74, 1342-1348) and in this study, using a slightly different protocol, four new adducts, with higher chromatographic mobility, were detected at levels ranging from 50 to $230 \%$ of those previously described. When DNA was treated in vitro with activated ptaquiloside (APT) and analysed by butanol extraction or nuclease P1 treatment, only one adduct was detected by ${ }^{32} \mathrm{P}$-postlabeling. This adduct was not present in the DNA from mice treated with bracken fern or spores, suggesting either that bracken contains genotoxins other than ptaquiloside or that the metabolism of ptaquiloside produces genotoxins not reflected by activated ptaquiloside. However, as the ATP-derived adduct has been detected previously in ileal DNA of bracken-fed calves, species-specific differences in the metabolism of bracken genotoxins may exist, thereby leading to differences in their biological outcomes. @ 2001 Academic Press

Key Words: bracken fern; ptaquil loside; DNA adducts; ${ }^{32}$ P-postlabelling.

Bracken fern (genus Pteridium) has been described as one of the most common plants on the planet (TayIor, 1990) and it is the only plant that is known to cause tumours naturally in animals (Shahin et al., 1999). The toxicity and carcinogenicity of bracken fern to domestic and experimental animals has been extensively de-

\footnotetext{
${ }^{1}$ To whom correspondence should be addressed at School of Epidemiology and Health Sciences, University of Manchester, M 13 9PT UK. Fax: 61275 5595. E-mail: apovey@fsl.scg.man.ac.uk.
}

scribed (Evans and Mason, 1965; Evans, 1984; IARC, 1986; Pamacku and Price, 1969). This plant contains a number of toxic components, including flavonoid antioxidants such as quercertin and an unstable glycoside, ptaquiloside (PT), which is thought to be the principal carcinogenic compound present in bracken (Hirono et al., 1984a, 1987). Recent work indicates that other toxic compounds related to ptaquiloside are also present in bracken fern (Castillo et al., 1998) but in lower concentrations.

PT is stable at room temperatures but decomposes in aqueous solutions. Under acidic conditions it undergoes aromatisation by elimination of the glucose to give pterosin B, whereas under alkaline conditions it is activated to give a conjugated dienone (activated ptaquiloside: APT) upon the liberation of the sugar group (Fig. 1; Ojika et al., 1987)). APT has been shown to alkylate DNA via a reactive cyclopropyl ring to form a number of different DNA adducts (Ojika et al., 1987, 1989). The main labile adducts occur at the $\mathrm{N}-3$ of adenine, and to a minor extent with N-7 of guanine (Smith et al., 1994b; Kushida et al., 1994). This N3adenine selectivity has also been observed in anticarcinogenic alkylating agents possessing a cyclopropyl ring intermediate (Hurley et al., 1984; Shalder et al., 1999). Following nuclease P1 enrichment and ${ }^{32} \mathrm{P}$-postlabelling, a single adduct, as yet uncharacterised, was found in DNA from the ileum of bracken fed calves (Prakash et al., 1996) or APT dosed rats (Shahin et al., 1998), and in DNA treated in vitro with APT (Smith et al., 1994b). As ptaquiloside-N3 adenine adducts are labile and depurinate within $24 \mathrm{~h}$ (Prakash et al., 1996) they may not be readily detectable in the postlabeling assay. Previously, it has been demonstrated that administration of either extract or spores of bracken fern collected in the UK (Pteridium aquili- 

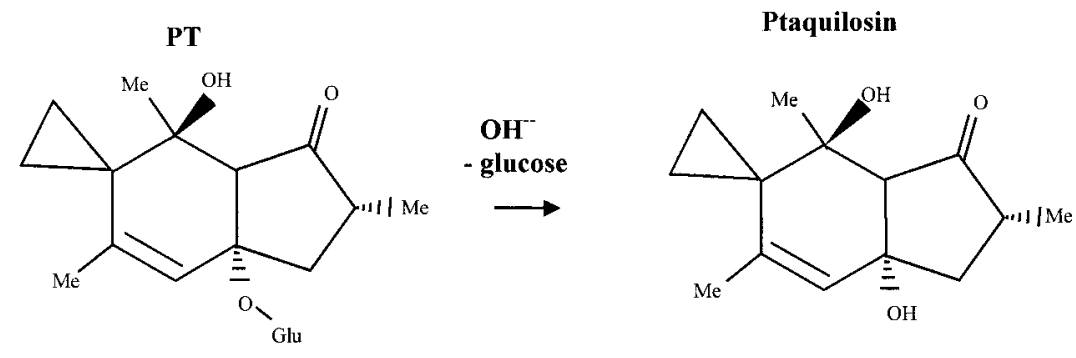

$$
\downarrow \mathbf{H}^{+}-\mathbf{H}_{2} \mathbf{O}
$$

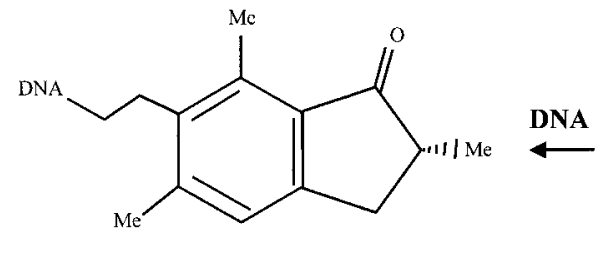

DNA adduct

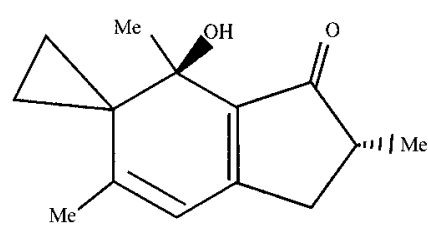

APT (dienone intermediate)

FIG. 1. Structures of ptaquiloside, ptaquilosin, activated ptaquiloside (APT), and its interaction with DNA.

num subsp. aquilinum) induced DNA adducts detectable in the upper gastrointestinal tract of BDF 1 mice by using ${ }^{32} \mathrm{P}$-postlabeling after butanol extraction for DNA adducts (Povey et al., 1996). However, the adduct enrichment method used in the former studies (Smith et al., 1994a; Prakash et al., 1996; Shahin et al., 1998) differed from that used in the UK study (Povey et al., 1996) and as these enrichment methods may extract chemically different adducts (Gupta and Early, 1988) it was not immediately apparent whether or not APTinduced DNA adducts were present in the DNA isolated from BDF 1 mice.

We thus carried out the present work, using both butanol and nuclease P1 enrichment procedures, to determine whether the uncharacterised adducts found in gastrointestinal tissue from BDF1 mice were the same or different from the one formed by APT in vitro.

\section{MATERIALS AND METHODS}

\footnotetext{
${ }^{32} \mathrm{P}-\gamma$-ATP (specific activity $7000 \mathrm{Ci} / \mathrm{mmol}$ ) was purchased from ICN Pharmaceuticals, Inc. (ICN Biomedicals, Kingston-uponThames, UK). $T_{4}$ polynucleotide kinase $\left(T_{4}-P N K\right)$ and calf spleen phosphodiesterase (CSPE) were both obtained from BoehringerMannheim (Germany). Micrococcal nuclease (MN) and alkaline phosphatase were obtained from Sigma (Poole, UK). MN and CSPE were also purchased from Worthington (Lorne Laboratories, Reading, UK). Plastic PEI-cellulose plates were supplied by SchleicherSchuell (Anderman and Co., Kingston-upon-Thames, UK).

\section{Preparation of Bracken Samples}

An extract of fresh bracken fern (Pteridium aquilinum subsp. aquilinum) collected in Bellech, Anglesey, UK was prepared (Povey et al., 1996). Ptaquiloside was isolated and purified as described
}

elsewhere (Oelrichs et al., 1995) from bracken collected from in Southeast Queensland.

\section{Treatment of Animals}

Treatment of animals with bracken fern extracts and spores from the UK has been described previously (Povey et al., 1996) and the DNA obtained in these experiments was used here.

\section{In Vitro Modification of DNA with Activated Ptaquiloside}

Ptaquiloside was activated by incubation with $\mathrm{NaOH}$ and used in vitro to modify calf thymus DNA (Smith et al., 1994a).

\section{Analysis of DNA Adducts}

DNA samples from the in vivo experiments were extracted using a standard phenol-chloroform method after treatment of the tissue with RNase A and proteinase K (Povey et al., 1996). Both butanol and nuclease $\mathrm{P} 1$ enrichment procedures were used to analyse for DNA adducts by ${ }^{32} \mathrm{P}$-postlabelling.

DNA digestion to nucleotides. $10-25 \mu \mathrm{g}$ of each DNA sample was

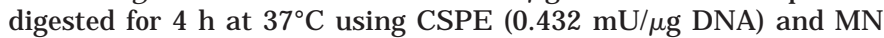
(0.495 U/ $\mu \mathrm{g}$ DNA) obtained from Worthington, with $10 \mathrm{mM}$ Tris$\mathrm{HCl}, \mathrm{pH} 7.4,5 \mathrm{mM} \mathrm{CaCl}$ and $1 \mu \mathrm{M}$ deoxycorfomycin in a final volume of $2.5 \mu \mathrm{l} / \mu \mathrm{g}$ DNA.

Butanol extraction. Aliquots containing $4 \mu \mathrm{g}$ of the DNA digest were extracted with 1-butanol (Povey et al., 1996) but using 3 rather than 2 back washes with 1-butanol saturated water.

Nuclease $\mathrm{P} 1$ digestion. Aliquots containing $7.89 \mu \mathrm{g}$ of the initial DNA digest was further incubated with sodium acetate $\mathrm{pH} 5$, zinc chloride, and nuclease $\mathrm{P} 1$ at final concentrations of $40 \mathrm{mM}, 0.2 \mathrm{mM}$, and $0.31 \mu \mathrm{g} / \mu \mathrm{l}$, respectively. The reaction was allowed to proceed for $30 \mathrm{~min}$ at $37^{\circ} \mathrm{C}$, then stopped by adding $1 \mu \mathrm{l}$ of $0.92 \mathrm{mM}$ Tris and the samples were dried in vacuo. 
A

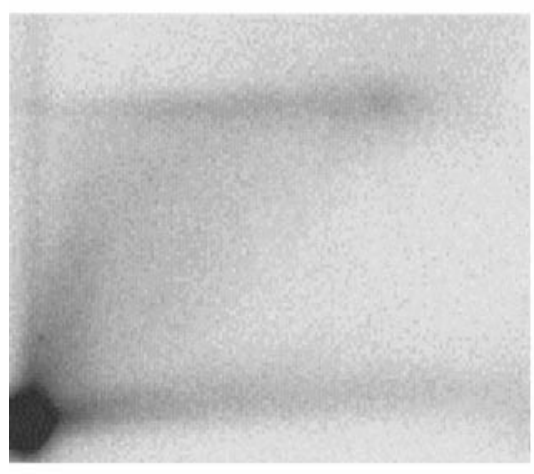

B

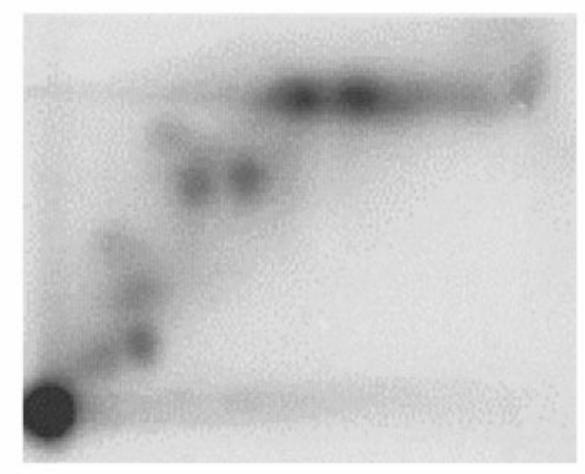

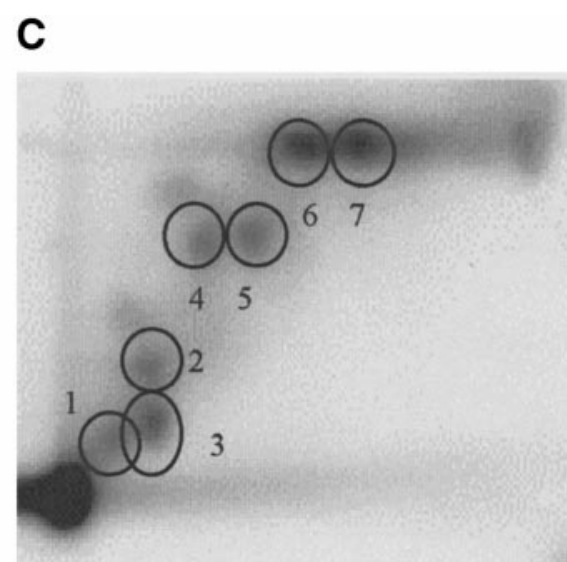

FIG. 2. Phosphorimages of butanol-extractable DNA adducts detected in the upper gastrointestinal tract of mice following treatment with water $(A)$, bracken fern extract $(B)$, and bracken spores (C).

\begin{abstract}
${ }^{32} \mathrm{P}$-postlabelling and TLC. The adducted nucleotides were ${ }^{32} \mathrm{P}$ postlabelled for $30 \mathrm{~min}$ at $37^{\circ} \mathrm{C}$ in $30 \mathrm{mM}$ Tris- $\mathrm{HCl}(\mathrm{pH} \mathrm{9.5)}$ containing $10 \mathrm{mM}$ magnesium chloride, $10 \mathrm{mM}$ DTT, $1 \mathrm{mM}$ spermidine, 3.0 $\mu$ M ATP (total concentration) using 2.5 units $\mathrm{T}_{4}$ PNK and $170 \mu \mathrm{Ci}$ ${ }^{32} \mathrm{P}-\gamma$-ATP in a total volume of $10 \mu \mathrm{l}$. Labelled samples were spotted on PEI-cellulose TLC plates and chromatographed as previously described (Povey et al., 1996) but with the plates only run once in D3 and D4. Solvents used for development of the thin layer plates were as follows: D1, 1.0 M sodium phosphate, $\mathrm{pH}$ 6.5; D3, $3.5 \mathrm{M}$ lithium formate, 8.5 M urea, $\mathrm{pH}$ 3.5; D4, 1.2 M lithium chloride, 0.5 M Tris, 8.5 M urea, $\mathrm{pH}$ 8; and D5, 1.7 M sodium phosphate, $\mathrm{pH} 6$.
\end{abstract}

Normal nucleotides and adduct quantitation. The plates were dried and exposed to a phosphorimager screen for up to $72 \mathrm{~h}$. The samples were visualised using a Molecular Dynamic Storm 860 image analysis system with ImageQuant software. Adducts were quantified by comparing the signal with that of a known amount of the labelling mix spotted onto a TLC plate and exposed together on the same phosphor screen. To determine the normal levels of nucleotides released, $10 \mu \mathrm{g}$ aliquots of the same DNA digest were treated with alkaline phosphatase to give nucleosides that were quantified by HPLC (Cooper et al., 1992).

\section{RESULTS}

Upper gastrointestinal DNA samples (oesophagus, stomach and ileum) from BDF 1 mice treated intragastrically with bracken extract or spores contained several adducts (Figs. 2B and $2 \mathrm{C}$ ) that were not found in the DNA samples from untreated control animals (Fig. $2 \mathrm{~A}$ ), or in untreated calf thymus DNA used as a negative control (data not shown). The adducts located near to the origin (Nos. 1, 2, and 3 in Fig. 2C) were described previously (Povey et al., 1996). In addition to these adducts, 4 other spots with higher chromatographic mobility were detected (Nos. 4-7 in Fig. 2C). Assuming quantitative recovery, the levels of adducts 4 and 5 were 50 and $90 \%$ of adduct 2 respectively whereas levels of adducts 6 and 7 were, respectively, 160 and $230 \%$ higher than the level of adduct 2 . Adducts recovered using butanol extraction were similar to those recovered using nuclease $\mathrm{P} 1$ digestion, except for ad- duct 1 , which was poorly recovered after nuclease P1 digestion (Fig. 3).

Only one adduct was detected in calf thymus DNA reacted in vitro with $A P T$ when the sample was treated with either nuclease P1 APT (Fig. 4) or extracted with butanol (data not shown). This APT derived adduct had a chromatographic mobility that was similar to adducts 6 and 7 but subsequent cochromatography experiments indicated a chemically different identity for the APT-derived adduct. Hence, we conclude that the APT induced DNA adduct was not present in detectable amounts in the DNA obtained from BDF 1 mice treated with bracken fern extract or bracken spores.

\section{DISCUSSION}

Previously, the presence of DNA adducts in upper gastrointestinal tissue of BDF1 mice treated with a single dose of bracken extracts or spores has been described (Povey et al., 1996). Using butanol extraction to enrich the adducted nucleotides in these samples, three major (Nos. 1, 2, and 3: Fig. 2C) adducts were found that were not present in untreated animals. These adducts were not characterised, but their chromatographic mobility was similar to adducts formed in the same tissue from mice dosed with synthesised compounds containing a cyclopropyl ring (Povey et al., 1996).

Using a slightly different protocol, not only have the same spots in these samples been detected, but also at least 4 other adducts (Nos. 4, 5, 6, and 7) with higher chromatography mobility (Figs. 2B and $2 \mathrm{C}$ ) were found that were not present in the control samples (Fig. 2A). Procedures that result in the preferential enrichment of different adduct classes (Reddy and Randerath, 1986; Gupta and Early, 1988) were used to further characterise these adducts. The DNA samples were digested to nucleotides and then either extracted with 
A

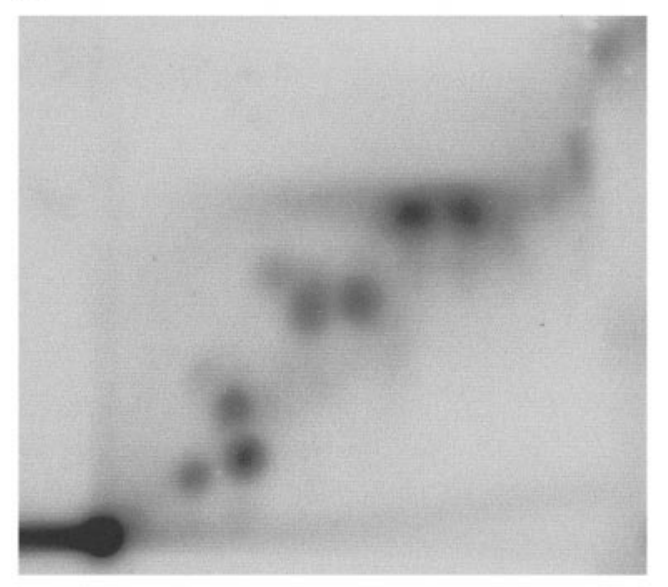

C

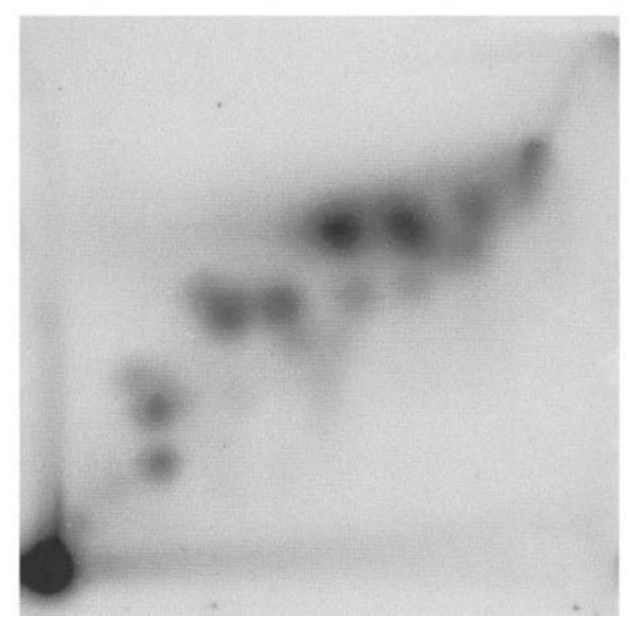

B

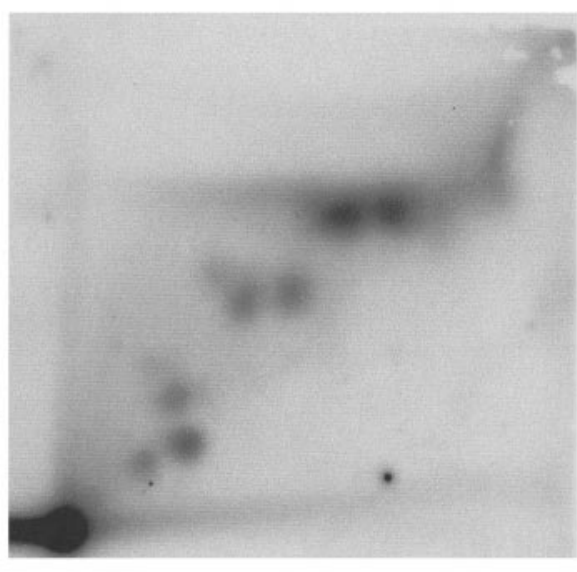

D

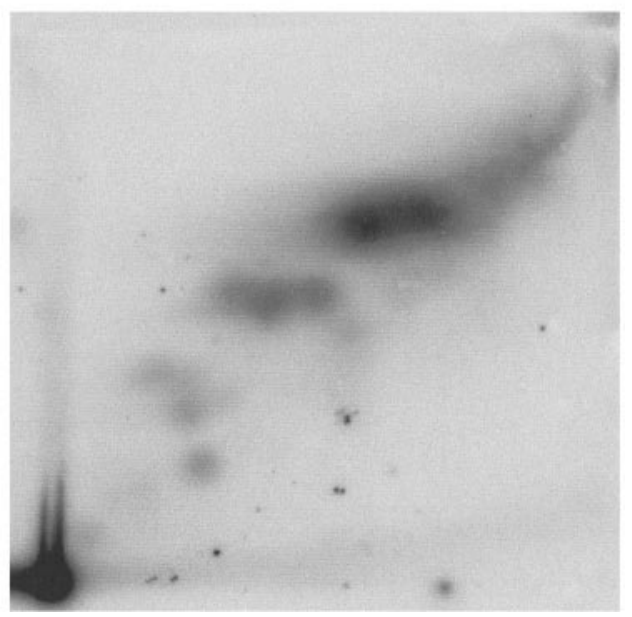

FIG. 3. Phosphorimages of DNA adducts detected in the upper gastrointestinal tract of mice following treatment with bracken fern extract $(A, C)$ or bracken spores (B, D). DNA from treated animals was enzymatically digested to nucl eotides and then subjected to butanol extraction (A, B) or further treatment with nuclease $\mathrm{P}_{1}(\mathrm{C}, \mathrm{D})$. The adducts were ${ }^{32} \mathrm{P}$-postlabelled and chromatographed on $\mathrm{PEI}$-cellulose plates as described in the text.

1-butanol (Gupta, 1985) or treated with nuclease P1 (Reddy and Randerath, 1986). Most of the adducts (Nos. 2-7, Fig. 2C) were readily detected by both techniques indicating that these were not sensitive to nuclease P1 digestion unlike certain adducts, notably those derived from aromatic amines or simple alkylating agents and some cyclic nucleotide adducts (Reddy et al., 1984; Hemmink et al., 1991; Szyfter et al., 1991; Vaca et al., 1992).

In order to know if any of the adducts detected in mouse DNA were identical to that formed by APT in vitro, a cochromatography experiment was performed (Fig. 4). This indicated that the principal DNA adduct formed by APT in vitro was not found in digests of the upper gastrointestinal tissue DNA of mice treated with bracken fern extracts or spores. The amount of PT in the bracken fern extract and bracken spores used in the mouse experiments was not quantified, but it was previously calculated that approximately $8 \mathrm{mg}$ of ptaquiloside was administered to each animal (Povey et al., 1996) based on a published bracken fern content (Hirono, 1986). However, as PT levels can depend on a number of factors including bracken species, freshness, season and drying conditions (Oelrichs et al., 1995; Smith et al., 1994b), the amount of PT in these samples may have been too low to permit the detection of PTderived DNA adducts. In a previous work, we (Shahin et al., 1998) could detect in ileum tissue a PT derived DNA adduct from rats dosed intravenously with $3 \mathrm{mg}$ ptaquiloside weekly for 10 weeks. Although, the absence of PT derived DNA adducts may potentially be ascribed to insufficient PT in the initial bracken extract, the presence of DNA adducts as detected by ${ }^{32} \mathrm{P}$-postlabelling, clearly indicates that the bracken samples did contain other genotoxins: whether these are unrelated to PT, or could arise from the metabolism of PT to forms other than APT remains to be determined. However, as an adduct similar to that arising 
A

B

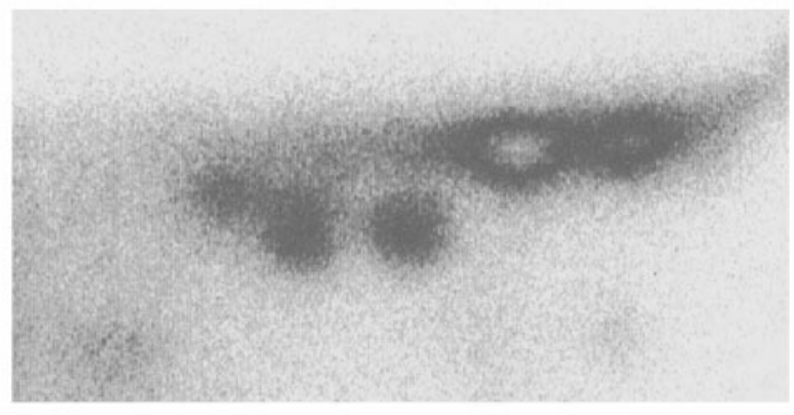

D

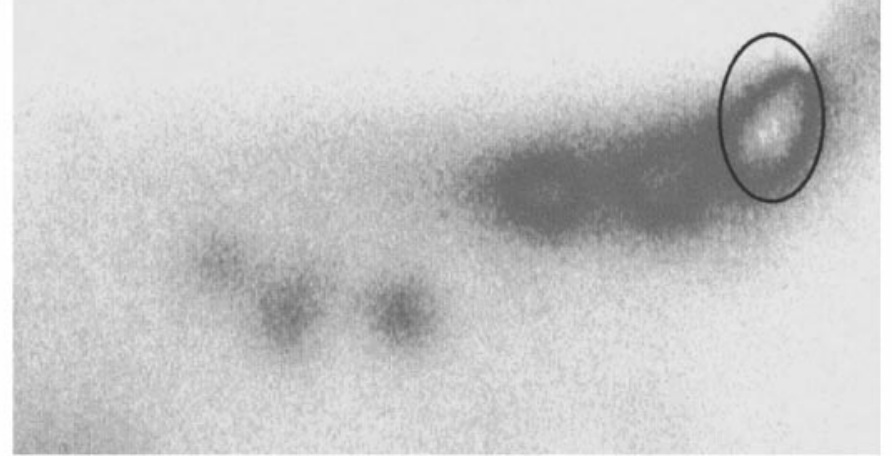

C

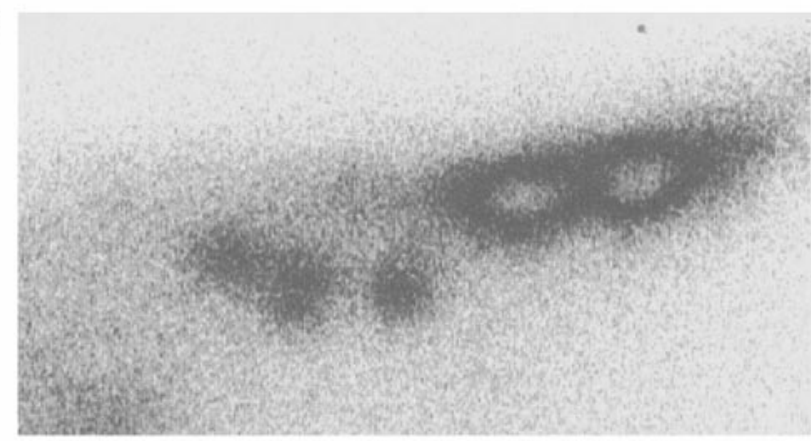

E

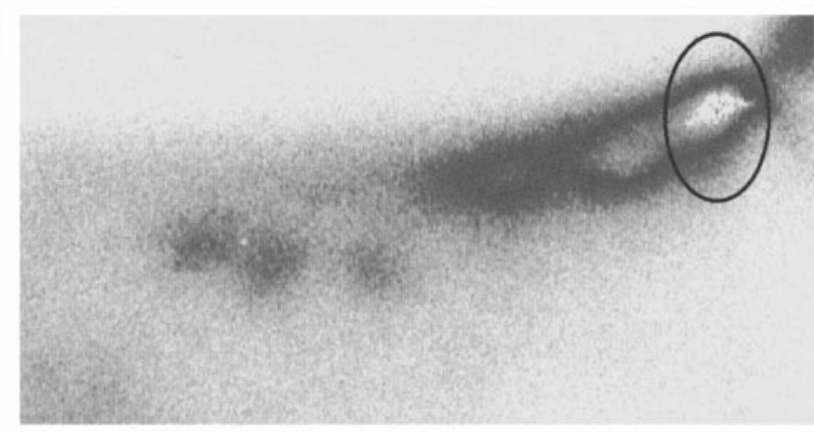

FIG. 4. Phosphorimages of high mobility DNA adducts detected in calf thymus DNA modified in vitro with APT (A) and the upper gastrointestinal tract of mice following treatment with bracken fern extract (B) or bracken spores (C). D and $E$ are respectively ${ }^{32} P$ postlabelled samples of DNA adducts induced by bracken fern extract (as in B) and bracken spores (as in C) cochromatographed with the adduct from calf thymus DNA modified in vitro with APT (as in A). Circles in D and E locate the APT-derived adduct.

from APT-DNA (Prakash et al., 1996), was found in the ileum from a calf fed with bracken fern, species specific differences in PT metabolism may exist. In this regard, it is of interest to note that in calves, the most important site of tumour occurrence is the ileum, followed by urinary bladder and mammary gland whereas in mice, leukaemic, stomach and lung tumours are common but with ileal tumours being a relatively rare occurrence (Evans, 1984; IARC, 1985).

In summary, DNA adducts derived from APT were not detected in tissues from mice treated with Pteridium aquilinum. The possibility that this is due to low PT levels in the bracken samples used to treat the mice cannot be ruled out. However as other DNA ad- ducts were detected following treatment with Pteridium aquilinum in mice, it is evident that there is more than one genotoxic substance is present in Pteridium aquilinum. Whether these genotoxins are related to the new PT-like compounds such as Ptaquiloside Z (Castillo et al., 1998) that are now being identified remains to be determined.

\section{ACKNOWLEDGMENTS}

The authors are grateful to Dr. Barry Smith, AgResearch, NZ, for his helpful comments; to the CNPq and CAPES of the Brazilian government and from FAPEMIG from Minas Gerais State government, Brazil, for grants to support R.N.F.; the Cancer Research 
Campaign for long-term funding; and also to the British Council for facilitating the interchange contacts.

\section{REFERENCES}

Castillo, U. F., Ojika, M., Alonso-Amelot, M., and Sakagami, Y. (1998) Ptaquiloside Z, a new toxic unstable sesquiterpene glucoside from the neotropical bracken fern Pteridium aquilinum var. caudatum. Bioorg. Med. Chem. 6, 2229-2233.

Evans, I. A. (1984) Bracken carcinogenicity. In Chemical Carcinogenesis (Searle, C. E., Ed.), pp. 1171-1204. American Chemical Society Monograph 182, Washington, DC.

Evans, I. A., and Mason, J. (1965) Carcinogenicity activity of bracken. Nature 208, 913-914.

Gupta, R. C. (1985) Enhanced sensitivity of ${ }^{32} \mathrm{P}$-postlabeling analysis of aromatic carcinogen:DNA adducts. Cancer Res. 45, 56565662.

Gupta, R. C., and Early, K. (1988) ${ }^{32}$ P-adduct assay: Comparative recoveries of structurally diverse DNA adducts in the various enhancement procedures. Carcinogenesis 9, 1687-1693.

Hemminki, K., Szyfter, K., and Kadublar, F. F . (1991) Quantitation of the ${ }^{32} \mathrm{P}$-postlabeling reaction using cyclic N 1, $\mathrm{N}^{2}$ and $\mathrm{C} 8$ modified deoxyguanosine-3-monophosphates as substrates. ChemBiol. Interact. 77, 51-61.

Hirono, I. (1986) Carcinogenicity of plant constituents: Pyrrolizidine alkaloids, bracken fern. In Genetic Toxicology of the Diet (Knudsen, I., Ed.), pp. 45-53. Alan Liss, New York.

Hirono, I., Yamada, K., Niwa, N., Shizuri, M., Ojika, M., Hasaka, S., Yamaji, T., Wakamatsu, K., Kigashi, H., Nuyama, K., and Uosakki, Y. (1984a) Separation of carcinogenic fraction of bracken fern. Cancer Lett. 21, 239-246.

Hirono, I., Aiso, S., Yamaji, T., Mori, H., Yamada, K., Niwa, H., Ojika, M., Wakamatsu, K., Kigoshi, H., Niiyama, K., and Uosaki, Y. (1984b) Carcinogenicity in rats of ptaquiloside isolated from bracken. Gann 75, 833- 836.

Hirono, I., Ojino, H., Fujimoto, M., Yamada, K., Yoshida, Y., I gawa, M., and Okumura, M. (1987) Induction of tumours in ACl rats given a diet containing ptaquiloside, a bracken carcinogen. J. Natl. Cancer Inst. 79, 1143-1149.

Hurley, L. H., Reynolds, V. L., Swenson, D. H., Petzold, G. L., and Scahill, T. A. (1984) Reaction of the antitumor antibiotic CC1065 with DNA: Structure of a DNA adduct with DNA sequence specificity. Science 226, 843- 844.

IARC (1986) Bracken fern (Pteridium aquilinum) and some of its constituents. In Monographs on the Evaluation of Carcinogenic Risk to Humans. No. 40. pp. 47-65. WHO, IARC, Lyon.

Kushida, T., Uesugi, M., Sugiura, Y., Kigoshi, H., Tanaka, H., Hirokawa, J., Ojika, M., and Yamada, K. (1994) DNA damage by ptaquiloside, a potent bracken carcinogen: Detection of selective strand breaks and identification of DNA cleavage products. J. Am. Chem. Soc. 116, 479- 486.

Oelrichs, P. B., Ng, J., and Bartley, J. (1995) Purification of ptaquiloside, a carcinogen from Pteridium aquilinum. Phytochemistry 40(1), 53-56.

Ojika, M., Wakamatsu, K., Niwa, H., and Yamada, K. (1987) Ptaquiloside, a potent carcinogen isolated from bracken fern Pteridium aquilinum var. Iaticulum. Structure elucidation based on chemical and spectral evidence and reactions with amino acids, nucleosides and nucleotides. Tetrahedron 43, 5261-5274.

Ojika, M., Sugimoto, K., Okazaki, T., and Yamada, K. (1989) Modification and cleavage of DNA by ptaquiloside. A new potent carcinogen isolated from bracken fern. Chem. Soc. Chem. Commun., 1775-1777.

Pamacku, A. M., and Price, J . M. (1969) Induction of urinary bladder cancer in rats by feeding bracken fern (Pteris aquilina). J . Natl . Cancer Inst. 43, 275-281.

Prakash, A. S., Pereira, T. N., Smith, B. L., Shaw, G., and Seawright, A. A. (1996) Mechanism of bracken fern carcinogenesis: Evidence for $\mathrm{H}$-ras activation via initial adenine alkylation by ptaquiloside. Nat. Toxins 4, 221-227.

Povey, A. C., Potter, D., and O'Connor, P. J . (1996) ${ }^{32}$ P-postlabeling analysis of DNA adducts formed in the upper gastrointestinal tissue of mice fed bracken extract or bracken spores. Br. J . Cancer 74, 1342-1348.

Reddy, M. V., and Randerath, K. (1986) Nuclease P1-mediated enhancement of sensitivity of ${ }^{32} \mathrm{P}$-postlabeling test for structurally diverse DNA adducts. Carcinogenesis 7, 1543-1551.

Reddy, M. V., Gupta, R. C., Randerath, E., and Randerath, K. (1984) ${ }^{32} \mathrm{P}$-postlabeling test for covalent DNA binding of chemicals in vivo: Application to a variety of aromatic carcinogens and methylating agents. Carcinogenesis 5, 231-243.

Shahin, M., Smith, B. L., Worral, S., Moore, M. R., Seawright, A. A., and Prakash, A. S. (1998) Bracken fern carcinogenesis: Multiple intravenous doses of activated ptaquiloside induce DNA adducts, monocytosis, increased TNF $\alpha$ levels and mammary gland carcinoma in rats. Biochem. Biophys. Res. Commun. 244, 192197.

Shahin, M., Snith, B. L., and Prakash, A. S. (1999) Bracken carcinogens in the human diet. Mutat. Res. 443, 69-79.

Shalders, R. L., Blanch, G., Brown, C. L., Young, D. J ., and Prakash, A. S. (1999) Stability and DNA alkylation rates of simplest functional analogs of CC-1065, p-hydroxy and p-amino phenethyl bromides. Chem.-Biol. I nteract. 117, 83-94.

Smith, B. L., Shaw, G., Prakash, A. S., and Seawright, A. A. (1994a) Studies on DNA adduct formation by ptaquiloside, the carcinogen of bracken ferns (Pteridium spp.). In Plant Associated Toxins (Colgate, S. M., and Dorling, P. R., Eds.), Chap. 31, pp. 167-172. CAB International, Wallingford, UK.

Smith, B. L., Seawright, A. A., Ng, J . C., Hertle, A. T., Thomson, J . A., and Bostock, P. D. (1994b) Concentration of ptaquiloside, a major carcinogen in bracken fern (Pteridium spp.), from eastern Australia and from a cultivated worldwide collection held in Sydney, Australia. Nat. Toxins 2, 347-353.

Szyfter, K., Hemminki, K., Crane, A. E., and Watson, W. P. (1991) Quantitative and kinetic examination of ${ }^{32} \mathrm{P}$-postlabeling of etheno-substituted nucleotides. Chem.-Biol. Interact. 80, 99107.

Taylor, J . A. (1990) The bracken problem: A global perspective. AIAS Occasional Publ. 40, 3-19.

Vaca, C. E., Vodicka, P., and Hemminki, K. (1992) Determination of malonaldehyde-modified 2-deoxyguanosine-3'-monophosphate and DNA by ${ }^{32} \mathrm{P}$-postlabeling. Carcinogenesis 13, 593-599. 